\title{
ANALISIS KUAT TARIK BELAH BETON PADA STANDAR KUAT TEKAN K200 DENGAN MENGGUNAKAN LIMBAH PECAHAN TEMPURUNG KELAPA SEBAGAI PENGGANTI AGREGAT KASAR
}

\author{
Asri Mulyadi $^{1)}$, Pengki Suanto ${ }^{2)}$, Ricki Meiza ${ }^{3)}$ \\ ${ }^{1), 2)}$ Dosen Universitas Palembang \\ ${ }^{3)}$ Dinas PUBMTR Prov. Sumatera Selatan \\ e-mail: asri_anang@yahoo.co.id ${ }^{1)}$, pengkisuanto@gmail.com ${ }^{2)}$,rickimeiza@gmail.com ${ }^{3)}$
}

\begin{abstract}
ABSTRAK
Beton merupakan faktor utama dalam bidang konstruksi pada saat ini bahan yang sangat penting dan paling dominan digunakan pada struktur bangunan. Beton sangat diminati karena bahan ini merupakan bahan konstruksi yang mempunyai banyak kelebihan antara lain, mudah dikerjakan dengan cara mencampur semen, agregat halus, agregat kasar, air, dan bahan tambahan lain bila diperlukan dengan perbandingan tertentu. Untuk itu bahan konstruksi ini dianggap sangat penting untuk terus dikembangkan, salah satu inovasi adalah penggantian agregat kasar sebagai salah satu bahan penyusun beton, yakni menggunakan limbah pecahan tempurung kelapa karena secara fisologis bagian tempurung kelapa merupakan struktur yang keras disebabkan oleh silikat ( $\mathrm{SiO} 2$ ) yang cukup tinggi kadarnya pada tempurung kelapa tersebut. Sehingga hal ini memungkinkan penggunaan tempurung kelapa dapat digunakan sebagai bahan pengganti agregat kasar. Tujuan dari penelitian ini ialah untuk mengetahui kuat tarik belah beton normal dengan beton memakai bahan limbah pecahan tempurung kelapa dengan variasi 5\%, 10\%,dan 15\% sebagai pengganti agregat kasar dalam campuran mutu beton rencana K200, benda uji di cetak dengan menggunakan silinder beton dengan umur 7, 14, 21, dan 28 hari. Dari hasil uji kuat tarik belah beton yaitu pada beton normal dengan umur 14, 21, dan 28 hari didapat kuat tarik belah beton diatas kuat tarik belah beton rencana 3,76 N/mm ${ }^{2}$. Kuat tarik belah beton yang dicapai oleh beton dengan menggunakan limbah pecahan tempurung kelapa 5\% dengan umur 7, 14, 21, dan 28 hari didapat kuat tarik belah beton relatif rendah dari kuat tarik belah beton rencana $3,76 \mathrm{~N} / \mathrm{mm}^{2}$. Begitu juga kuat tarik belah beton yang dicapai oleh beton dengan menggunakan limbah pecahan tempurung kelapa 10\%,15\% dengan umur 7, 14, 21, dan 28 hari didapat kuat tarik belah beton relatif rendah.
\end{abstract}

Kata Kunci : Beton, kuat tarik belah, limbah pecahan tempurung kelapa.

\section{PENDAHULUAN}

\section{A. Latar Belakang}

Beton merupakan faktor utama dalam bidang konstruksi pada saat ini bahan yang sangat penting dan paling dominan digunakan pada struktur bangunan. Beton sangat diminati karena bahan ini merupakan bahan konstruksi yang mempunyai banyak kelebihan antara lain, mudah dikerjakan dengan cara mencampur semen, agregat halus, agregat kasar, air dan bahan tambahan lain bila diperlukan dalam perbandingan tertentu. Kelebihan beton yang lain adalah, ekonomis (dalam pembuatannya menggunakan bahan dasar lokal yang mudah diperoleh), dapat dibentuk sesuai dengan kebutuhan yang dikehendaki, mampu menerima kuat tekan dengan baik, tahan aus, rapat air, awet dan mudah perawatannya, maka beton sangat populer dipakai baik untuk struktur-struktur besar maupun kecil [1]. Seiring dengan perkembangan saat ini, inovasi campuran beton telah banyak dilakukan diantaranya dengan memanfaatkan bahan limbah sebagai bahan pengganti agregat dan Zat Aditif sebagai bahan tambah dalam upaya meningkatkan kualitas beton. Tidak selamanya limbah terbuang percuma, tetapi tidak sembarang limbah bisa dijadikan bahan untuk kontruksi. Mengingat kita sebagai perekayasa konstruksi juga tidak seharusnya melupakan kedamaian serta keasrian lingkungan sekeliling kita. Secara fisologis bagian tempurung kelapa merupakan struktur yang keras disebabkan oleh silikat ( $\mathrm{SiO} 2)$ yang cukup tinggi kadarnya pada tempurung kelapa tersebut [2]. Sehingga 
hal ini memungkinkan penggunaan tempurung kelapa dapat digunakan sebagai bahan pengganti agregat kasar.

\section{B. Tujuan Penelitian}

Adapun tujuan penelitian ini adalah :

1. Membandingkan kuat tarik belah beton normal dengan beton memakai bahan limbah tempurung kelapa sebagai pengganti agregat kasar dalam campuran beton.

2. Mengetahui pengaruh limbah tempurung kelapa sebagai pengganti agregat kasar dengan variabel tertentu terhadap kuat tarik belah beton.

3. Untuk mengetahui nilai optimal kuat tarik belah beton pada beton dari komposisi campuran pengganti agregat kasar dari limbah tempurung kelapa.

\section{Manfaat Penelitian}

Akan memberikan pengetahuan dan pemahaman yang lebih mendalam tentang pemanfaatan limbah tempurung kelapa sebagai pengganti agregat kasar pada campuran beton, sehingga mampu memberikan kontribusi yang besar dalam perkembangan teknologi beton di dunia Teknik Sipil.

\section{Rumusan Masalah}

Permasalahan yang akan dibahas dalam penelitian ini adalah sebagai berikut :

1. Bagaimana pengaruh limbah Tempurung Kelapa sebagai pengganti agregat kasar tersebut terhadap kuat tarik belah beton.

2. Bagaimana pengaruh perbandingan beberapa variabel campuran limbah Tempurung Kelapa sebagai pengganti agregat kasar terhadap kuat tarik belah beton.

\section{E. Batasan Masalah}

Batasan masalah di dalam penelitian ini penulis membatasi ruang lingkup pekerjaan pengujian - pengujian bahan material dan benda uji kuat tarik belah beton di laboratorium. Penelitian dilakukan terhadap beton dengan membandingkan antara beton normal dengan beton yang menggunakan limbah Tempurung Kelapa sebagai pengganti agregat kasar, perlakuan yang diambil pada penelitian ini sebanyak 4 perbandingan yaitu ;
2. Beton dengan menggunakan limbah Tempurung Kelapa sebagai pengganti agregat kasar sebesar 5\%.

3. Beton dengan menggunakan limbah Tempurung Kelapa sebagai pengganti agregat kasar sebesar $10 \%$.

4. Beton dengan menggunakan limbah Tempurung Kelapa sebagai pengganti agregat kasar sebesar $15 \%$.

Penelitian yang dilakukan meliputi kuat tarik belah beton. Pengujian dilakukan pada umur beton 7 hari, 14 hari 21 hari dan 28 hari.

\section{TINJAUAN PUSTAKA}

\section{A. Beton}

Beton yang digunakan sebagai struktur dalam konstruksi Teknik Sipil dapat dimanfaatkan untuk banyak hal seperti untuk bangunan pondasi, kolom, balok, pelat lantai. Dalam teknik sipil hidro, beton yang digunakan untuk bangunan air seperti bendungan, saluran dan drainase. Beton merupakan fungsi dari bahan penyusun yang terdiri bahan semen hidrolik (Porlantd Sement), agregat kasar, agregat halus, air, dan bahan tambah (admixture atau additive) [3]. Campuran tersebut akan mengeras seperti batuan, pengerasan terjadi karena peristiwa reaksi kimia antara semen dengan air. Beton yang sudah mengeras dapat juga dikatakan sebagai batuan tiruan, dengan rongga-rongga antara butiran yang besar (agregat kasar atau batu pecah), dan di isi oleh batuan kecil (agregat halus atau pasir), dan pori-pori antara agregat halus di isi oleh semen dan air (pasta semen). Pasta semen juga berfungsi sebagai perekat atau pengikat dalam proses pengerasan, sehingga butiran-butiran agregat saling terekat dengan kuat sehingga terbentuklah suatu kesatuan yang padat dan tahan lama. Beton keras yang baik adalah beton yang kuat, tahan lama, kedap air, tahan aus, dan kembang susutnya kecil [4]

\section{B. Agregat}

Agregat merupakan butiran mineral alami atau buatan yang berfungsi sebagai bahan pengisi dari campuran beton. Agregat menempati $\pm 70 \%$ volume beton, sehingga sangat berpengaruh terhadap sifat ataupun kualitas beton, sehingga pemilihan agregat 
merupakan bagian yang sangat penting dalam pembuatan beton [5].

\section{Semen Portland}

Semen portland ialah semen hidrolis yang dihasilkan dengan cara menghaluskan klinker yang terdiri dari silikat-silikat kalsium yang bersifat hidrolis dengan gips sebagai bahan tambahan [6]. Fungsi semen ialah untuk merekatkan butir-butir agregat agar terjadi suatu massa yang kompak atau padat, selain itu juga untuk mengisi rongga diantara butiranbutiran agregat.

\section{Air}

Air merupakan bahan dasar yang sangat penting dalam pembuatan beton. Air diperlukan untuk bereaksi dengan semen serta menjadi bahan pelumas antara butir-butir agregat sehingga mudah dipadatkan. Di dalam penggunaannya, air tidak boleh terlalu banyak karena akan menyebabkan menurunnya kekuatan beton itu sendiri. Air yang digunakan untuk pembuatan beton harus bersih dan tidak mengandung minyak, tidak mengandung alkali, garam-garaman, zat organis yang dapat merusak beton atau baja tulangan [7]. Air tawar yang biasanya diminum baik air diolah oleh PDAM atau air dari sumur yang tanpa diolah dapat digunakan untuk membuat beton.

\section{E. Limbah Pecahan Tempurung Kelapa}

Tempurung kelapa merupakan bagian dari buah kelapa yang masih belum banyak dimanfaatkan dibandingkan dengan bagian buah kelapa lainnya, meskipun sebagian kecilnya sudah diolah menjadi tempurung kelapa dan arang. Berat dan tebal tempurung kelapa ditentukan oleh jenis tanaman kelapa. Berat tempurung sekitar $15-19 \%$ bobot total buah kelapa dengan ketebalan 3-5 mm. Tempurung kelapa termasuk golongan kayu keras, secara kimiawi memiliki komposisi kimiawi yang hampir mirip dengan kayu yaitu tersusun dari lignin $36,51 \%$, selulosa $33,61 \%$, semiselulosa $29,27 \%$ [8].

\section{F. Rencana Campuran Beton}

Perencanaan campuran beton adalah suatu cara untuk menentukan perbandingan bahan-bahan campurannya sedemikian sehingga untuk keadaan tertentu dihasilkan beton dengan sifat - sifat yang diisyaratkan dan dengan harga ekonomis.

\section{G. Slump}

Pengujian nilai Slump ialah salah satu cara untuk mengukur kecelakaan beton segar yang dipakai pula untuk memperkirakan tingkat kemudahan dalam pengerjaannya. dalam pelaksanaannya nilai Slump untuk berbagai pekerjaan pembetonan harus disesuaikan dengan syarat yang sesuai dengan pemakaiannya [9].

\section{H. Kuat Tarik Belah Beton}

Pemeriksaan kuat tarik belah beton dilakukan untuk mengetahui secara pasti akan kekuatan tarik belah beton pada umur 7,14, 21, dan 28 hari yang sebenarnya apakah sesuai dengan yang direncanakan atau tidak. Pada mesin uji tekan benda diletakkan dan diberikan beban sampai benda runtuh, yaitu pada saat beban maksimum bekerja. Kuat tarik belah beton dari benda uji dapat dihitung dengan rumus [10] :

\section{$F c t=2 \mathrm{P} / \pi \mathrm{LD}$}

Dengan :

Fct $=$ Kuat tarik belah beton, $\mathrm{MPa}$

$\mathrm{P}=$ Beban uji maksimum (beban belah / hancur) dalam Newton $(\mathrm{N})$ yang ditunjukkan mesin uji tekan

$\mathrm{L}=$ Panjang benda uji, $\mathrm{mm}$

$\mathrm{D}=$ Diameter benda uji, $\mathrm{mm}$

\section{METODOLOGI PENELITIAN}

\section{A. Persiapan Peralatan dan Bahan}

Penelitian ini dilaksanakan di laboratorium Fakultas Teknik Universitas Palembang dan Labrotorium Sipil Politeknik Negeri Sriwijaya. Sebelum Penelitian dilakukan perlu adanya persiapan peralatan dan bahan. Peralatan yang digunakan terdiri dari :

1. Timbangan, alat untuk menimbang benda uji, agregat halus dan kasar dengan ketelitian $0,3 \%$.

2. Specific Gravity, alat ini digunakan untuk menentukan berat jenis agregat halus dan kasar dengan ketelitian $0,1 \%$.

3. Talam-talam, alat untuk mengeringkan material.

4. Pan Alumunium / Cawan

5. Cetakan Silinder Beton dengan ukuran panjang $300 \mathrm{~mm}$ dan diameter $150 \mathrm{~mm}$ 
6. Piknometer (Labu Ukur)

7. Mesin Penggetar

8. Centong

9. Kuas

10. Ember Plastik

11. Mistar Perata

12. Alat pengaduk campuran beton

13. Meteran

14. Bak Adukan, alat untuk tempat adukan terbuat dari plat yang datar dari bahan sejenis metal, kedap air dan mampu menahan beban adukan.

15. Oven yang dilengkapi pengatur suhu, alat yang digunakan untuk mengeringkan agregat halus dan agregat kasar

16. Satu set saringan / ayakan, untuk memeriksa agregat halus dan kasar.

17. Kerucut Terpancung, alat untuk mengukur kadar air pada campuran beton. Tongkat (penusuk) terbuat dari baja tahan karat gunanya adalah untuk pemadat.

18. Mesin Uji Kuat Tekan, alat untuk memeriksa kuat tekan beton.

Bahan-bahan yang dibutuhkan untuk penelitian ini antara lain:

1. Semen Portland type I ex. Baturaja

2. Agregat halus (Pasir) ex. sungai musi

3. Agregat kasar (Split) ex. Lahat

4. Limbah pecahan tempurung kelapa

5. Air adalah air bersih yang ada di laboratorium Fakultas Teknik

\section{B. Pemeriksaan Agregat}

Penggunaan agregat dalam beton mencapai $70 \%$ - $75 \%$ dari seluruh volume massa padat beton. Untuk mencapai kekuatan beton yang baik yang sesuai dengan yang direncanakan, maka perlu adanya pemeriksaan agregat.

\section{Pemeriksaan Agregat Halus}

- Berat jenis dan penyerapan air.

- Kadar lumpur dan lempung.

- Analisa ayak.

2. Pemeriksaan Agregat Kasar

- Berat jenis dan penyerapan air.

- Analisa ayak.

\section{Pemeriksaan limbah pecahan cangkang kelapa}

Pada penelitian ini material pengganti agregat kasar yang digunakan adalah limbah pecahan cangkang kelapa yang dipotong potong dengan ukuran $2 \mathrm{~cm}$ sampai $3 \mathrm{~cm}$ dengan desain pengganti agregat kasar 5\%, $10 \%, 15 \%$, dari berat agregat kasar.

\section{Perencanaan Campuran Beton}

Metode perencanaan campuran beton yang digunakan dalam penelitian ini dengan menggunakan campuran beton dengan mutu beton rencana fc' $16,9 \mathrm{MPa}$ (K.200). Dengan langkah kerja sebagai berikut :

1. Menentukan karakteristik kuat tarik belah beton K.200 pada umur 28 hari dengan jumlah cacat $5 \%$ dari banyak sample.

2. Menghitung kekuatan rata-rata yang akan dicapai dengan menjumlahkan hasil nomor $1+3$.

3. Menetapkan jenis semen yang digunakan adalah semen Portland type I

4. Menetapkan jenis agregat yang dipakai adalah :

- Agregat halus : alami

- Agregat kasar : alam / batu pecah / split

5. Faktor air semen ditentukan dengan berpedoman pada grafik kemudian disesuaikan dengan type semen yang dipakai dan kekuatan tekan yang direncanakan pada umur 28 hari.

6. Faktor air semen maksimum dapat dilihat pada tabel yang disesuaikan dengan kondisi penggunaan beton tersebut.

7. Menentukan tinggi slump dengan menyesuaikan kegunaan dari beton tersebut untuk konstruksi.

8. Ukuran kadar agregat ditentukan dari hasil analisa saringan dengan mengambil ukuran agregat maksimum lolos saringan.

9. Kadar air bebas dapat dilihat pada tabel disesuaikan dengan besarnya slump dan ukuran agregat maksimum.

10. Kadar semen tiap $\mathrm{m}^{3}$ beton dihitung dari perbandingan air dengan faktor air semen (No. 11 / No.7).

11. Kadar semen maksimum tidak ditentukan jadi dapat diabaikan.

12. Kadar semen minimum ditetapkan 352 $\mathrm{kg} / \mathrm{m}^{3}$.

13. Susunan besar butir agregat disesuaikan dengan analisa saringan yang ditentukan.

14. Persentase agregat halus diperoleh dari perbandingan gabungan antara agregat halus dan kasar (lihat pada lampiran).

15. Berat jenis relatif agregat kering permukaan diperoleh dari perbandingan rata-rata berat jenis agregat halus dan 
kasar.

16. Berat jenis beton diperoleh dari grafik dengan jalan membuat grafik baru yang sesuai dengan nilai berat jenis gabungan.

17. Kadar agregat gabungan = berat jenis, beton dikurangi jumlah kadar semen dan kadar air.

18. Kadar agregat halus persentase agregat halus (No. 16) x kadar agregat gabungan (No. 19).

19. Kadar agregat kasar kadar agregat gabungan (No. 19) dikurangi kadar agregat halus (No. 20).

Dari langkah No.1 sampai No.21, didapat susunan campuran beton teoritis untuk tiap $1 \mathrm{~m}^{3}$ yaitu diperlukan semen sebanyak (No.2), air (No.11), pasir (No.20), koral (No.21).

Dalam perhitungan yang telah dilakukan, agregat halus dan agregat kasar dalam keadaan jenuh kering permukaan (SSD) maka apabila material yang ada dilapangan tidak jenuh kering permukaan harus dilakukan koreksi terhadap kebutuhan bahannya.

\section{E. Pengujian Slump}

Peralatan yang digunakan dalam pengujian slump ini adalah meteran dan Kerucut Terpancung.

Langkah-langkah

pengerjaannya adalah sebagai berikut :

1. Kerucut terpancung dan pelat dibasahi dengan kain basah.

2. Letakkan kerucut terpancung di atas pelat.

3. Isi kerucut terpancung sampai penuh dengan beton segar dalam 3 lapisan, setiap, lapis berisi kira-kira 1/3 kerucut terpancung tersebut. Setiap lapis dipadatkan dengan 25 kali tumbukan secara merata. Pada pemadatan, tongkat harus tepat masuk sampai lapisan bagian bawah tiap lapisan.

4. Setelah selesai pemadatan ratakan permukaan benda uji dengan tongkat, tunggu selama 30 detik dan dalam jangka waktu ini semua benda uji yang jatuh disekitar kerucut harus disingkirkan.

5. Kemudian angkat kerucut secara perlahanlahan keatas secara tegak lurus.

6. Ukur slump yang terjadi dengan menentukan penurunan benda uji terhadap puncak kerucut terpancung.

Perhitungan : Besar Slump = Tinggi Penurunan Benda Uji

\section{ANALISIS DAN PEMBAHASAN}

\section{A. Pemeriksaan Agregat Halus (Pasir)}

Pengujian laboratorium yang dilakukan untuk agregat halus meliputi berat isi gembur dan berat isi padat, analisa saringan, berat jenis dan penyerapan, kadar lumpur dan kadar air, agregat halus yang digunakan adalah pasir sungai musi.

Dari hasil pemeriksaan yang telah dilakukan di laboratorium, didapat data - data seperti disajikan pada tabel berikut :

Tabel 4.1. Berat isi gembur dan berat isi padat agregat halus (Pasir)

\begin{tabular}{|c|c|c|c|c|c|c|}
\hline \multirow{2}{*}{ Kegiatan } & \multicolumn{2}{|c|}{ I } & \multicolumn{2}{|c|}{ II } & \multicolumn{2}{|c|}{ III } \\
\hline & Gembur & Padat & Gembur & Padat & Gembur & Padat \\
\hline A Volume & 1893,13 & 1893,13 & 1893,13 & 1893,13 & 1893,13 & 1893,13 \\
\hline B filinder & & & & & & \\
\hline $\begin{array}{l}\text { C Berat } \\
\text { silinder }\end{array}$ & 855 & 855 & 855 & 855 & 855 & 855 \\
\hline $\begin{array}{l}\text { Berat } \\
\text { Benda Uji }\end{array}$ & 2924 & 3258 & 2920 & 3230 & 2914 & 3288,5 \\
\hline $\begin{array}{l}\text { Berat } \\
\text { volume : } \\
\qquad C-B\end{array}$ & 1,093 & 1,269 & 1,091 & 1,255 & 1,088 & 1,285 \\
\hline$A$ & & & & & & \\
\hline $\begin{array}{rr}\text { Berat Volun } \\
- & 1 \\
- & 1 \\
\end{array}$ & $\begin{array}{l}\text { rata-rat } \\
\text { rat isi gen } \\
\text { rat isi pad }\end{array}$ & $\begin{array}{l}: \\
\text { bur }=1,09 \\
t \quad=1,26\end{array}$ & $\begin{array}{l}1 \mathrm{gr} / \mathrm{cm}^{3} \\
69 \mathrm{gr} / \mathrm{cm}^{3}\end{array}$ & & & \\
\hline
\end{tabular}

Sumber : Hasil penelitian

Tabel 4.2. Analisa Saringan Agregat Halus

\begin{tabular}{|c|c|c|c|c|}
\hline \multirow[t]{2}{*}{$\begin{array}{l}\text { Saringan } \\
(\mathrm{mm})\end{array}$} & \multirow{2}{*}{$\begin{array}{l}\text { Berat } \\
\text { tertahan } \\
\text { (gr) }\end{array}$} & \multirow{2}{*}{$\begin{array}{l}\text { Jumlah } \\
\text { berat } \\
\text { tertahan }\end{array}$} & \multicolumn{2}{|c|}{$\begin{array}{c}\text { Jumlah persen } \\
(\%)\end{array}$} \\
\hline & & & Tertahan & Lolos \\
\hline 4,75 & 0 & 0 & 0 & 100 \\
\hline 4 & 2 & 0,4 & 0,4 & 99,6 \\
\hline 2 & 4,5 & 0,9 & 1,3 & 98,7 \\
\hline 1 & 33 & 6,6 & 7,9 & 92,1 \\
\hline 0,5 & 30 & 6 & 13,9 & 86,1 \\
\hline 0,25 & 262,5 & 52,5 & 66,4 & 33,6 \\
\hline 0,125 & 153,5 & 30,7 & 97,1 & 2,9 \\
\hline 0,063 & 10 & 2 & 99,1 & 0,9 \\
\hline Pan & 4,5 & 0,9 & 100 & 0 \\
\hline Total & 500 & 100 & 386,1 & \\
\hline \multicolumn{5}{|c|}{$\frac{386,1}{100}=3,861$} \\
\hline
\end{tabular}

Sumber : Hasil penelitian

Tabel 4.3. Berat Jenis dan Penyerapan Agregat halus

\begin{tabular}{|l|l|c|c|}
\hline \multicolumn{2}{|c|}{ Kegiatan } & \multicolumn{2}{c|}{ Berat (gram) } \\
\cline { 3 - 4 } \multicolumn{2}{|c|}{} & I & II \\
\hline A & Berat cawan & 869 & 881 \\
B & Berat gelas ukur (1000 ml) & 303 & 303 \\
C & Berat gelas ukur + pasir + air & 1592,5 & 1594 \\
D & Berat gelas ukur + air & 1302 & 1302 \\
E & Berat cawan + pasir setelah dioven & 1367 & 1367 \\
& ( Kering Kerontang ) & & \\
\hline
\end{tabular}




\begin{tabular}{|l|c|c|}
\hline Berat jenis kering : $\frac{E-A}{D+500-C}$ & 2,387 & 2,337 \\
\hline Berat jenis SSD : $\frac{500}{D+500-C}$ & 2,450 & 2,404 \\
\hline Persentase penyerapan air : & 2,669 & 2,881 \\
$\frac{500-(E-A)}{E-A}$ & & \\
\hline Berat jenis kering rata - rata $=$ & \multicolumn{2}{|c|}{2,362} \\
Berat jenis SSD rata - rata $=$ & 2,427 \\
Persentase penyerapan rata - rata $=$ & $2,775 \%$ \\
\hline
\end{tabular}

Sumber : Hasil penelitian

Tabel 4.4. Kadar Lumpur Agregat halus

\begin{tabular}{|c|c|c|c|}
\hline \multirow{2}{*}{\multicolumn{2}{|c|}{ Kegiatan }} & \multicolumn{2}{|c|}{ Berat (gram) } \\
\hline & & I & II \\
\hline A & Berat Agregat & 736 & 987 \\
\hline B & Berat Cawan & 1000 & 1000 \\
\hline $\mathrm{C}$ & $\begin{array}{l}\text { Berat Cawan+aggregate } \\
\text { sebelum dicuci (kering) }\end{array}$ & 1736 & 1987 \\
\hline D & $\begin{array}{l}\text { Berat Cawan+aggregate } \\
\text { sebelum dicuci (di } \\
\text { oven) }\end{array}$ & 1729 & 1978 \\
\hline \multicolumn{2}{|c|}{$\begin{array}{l}\text { Kadar lumpur: } \\
(C-B)-(D-B)\end{array}$} & $0,705 \%$ & $0,908 \%$ \\
\hline & $(D-B)$ & & \\
\hline
\end{tabular}

Sumber : Hasil penelitian

Tabel 4.5. Kadar Air Agregat halus

\begin{tabular}{|c|c|c|c|}
\hline \multirow{2}{*}{\multicolumn{2}{|c|}{ Kegiatan }} & \multicolumn{2}{|c|}{ Berat (gram) } \\
\hline & & I & II \\
\hline A & Berat Aggregat & 815 & 824,50 \\
\hline B & Berat Cawan & 3000 & 3000 \\
\hline $\mathrm{C}$ & $\begin{array}{l}\text { Berat Cawan+aggregat } \\
\text { sebelum dicuci (kering) }\end{array}$ & 3815 & 3824,50 \\
\hline D & $\begin{array}{l}\text { Berat Cawan+aggregate } \\
\text { sebelum dicuci (di oven) }\end{array}$ & 3616 & 3624,50 \\
\hline \multicolumn{2}{|c|}{$\begin{array}{l}\text { Kadar Lumpur: } \\
(C-A)-(D-A)\end{array}$} & $7,11 \%$ & $7,14 \%$ \\
\hline & $(D-A)$ & & \\
\hline
\end{tabular}

Sumber : Hasil penelitian

\section{B. Pemeriksaan Agregat Halus (Pasir)}

Tabel 4.6. Pemeriksaan Kadar Air Agregat Kasar

\begin{tabular}{|l|c|c|}
\hline \multicolumn{1}{|c|}{ Pemeriksaan } & I (gram) & II (gram) \\
\hline Berat cawan $\left(\mathrm{W}_{1}\right)$ & 739 & 880 \\
\hline Berat cawan + Benda uji $\left(\mathrm{W}_{2}\right)$ & 1511 & 1731 \\
\hline Berat benda uji $\left(\mathrm{W}_{3}=\mathrm{W}_{2}-\mathrm{W}_{1}\right)$ & 772 & 851 \\
\hline
\end{tabular}

\begin{tabular}{|c|c|c|}
\hline Berat cawan + Benda uji kering oven $\left(\mathrm{W}_{4}\right)$ & 1484 & 1700 \\
\hline Berat benda uji kering oven $\left(\mathrm{W}_{5}=\mathrm{W}_{4}-\mathrm{W}_{1}\right)$ & 745 & 820 \\
\hline Kadar air agregat $=\frac{W_{3}-W_{5}}{W_{5}} \times 100 \%$ & $3,624 \%$ & $3,780 \%$ \\
\cline { 2 - 3 } & \multicolumn{2}{|c|}{$\begin{array}{c}\text { Rata }- \text { rata }= \\
3,702 \%\end{array}$} \\
\hline
\end{tabular}

Sumber : Hasil penelitian

Dari hasil pengujian kadar air agregat kasar didapat kan persentase sebesar 3,702\%

Tabel 4.7. Pemeriksaan Kadar Lumpur Agregat Kasar

\begin{tabular}{|l|c|c|}
\hline \multicolumn{1}{|c|}{ Pemeriksaan } & $\begin{array}{c}\text { I } \\
\text { (gram) }\end{array}$ & $\begin{array}{c}\text { II } \\
(\text { gram } \\
\text { ) }\end{array}$ \\
\hline Berat cawan $\left(\mathrm{W}_{1}\right)$ & 740 & 747 \\
\hline Berat cawan + Benda uji $\left(\mathrm{W}_{2}\right)$ & 1492 & 1401 \\
\hline Berat benda uji $\left(\mathrm{W}_{3}=\mathrm{W}_{2}-\mathrm{W}_{1}\right)$ & 752 & 654 \\
\hline Berat cawan + Benda uji kering oven $\left(\mathrm{W}_{4}\right)$ & 1467 & 1381 \\
\hline Berat benda uji kering oven $\left(\mathrm{W}_{5}=\mathrm{W}_{4}-\mathrm{W}_{1}\right)$ & 727 & 634 \\
\hline \multirow{2}{*}{ Kadar air agregat $=\frac{W_{3}-W_{5}}{W_{5}} \times 100 \%$} & $3,438 \%$ & 3,155 \\
\cline { 2 - 4 } & \multicolumn{2}{|c|}{ Rata - rata $=$} \\
\cline { 2 - 3 } & \multicolumn{2}{|c|}{$3,297 \%$} \\
\hline
\end{tabular}

Sumber : Hasil penelitian

Dari hasil pengujian kadar air agregat kasar didapatkan persentase sebesar $3,297 \%$

Tabel 4.8. Pemeriksaan Berat Jenis dan Penyerapan Air

\begin{tabular}{|l|c|c|}
\hline \multicolumn{1}{|c|}{ Pemeriksaan } & I (gram) & II (gram) \\
\hline Berat benda uji jenuh permukaan kering (Bj) & 500 & 500 \\
\hline Berat benda uji kering oven (Bk) & 485 & 494 \\
\hline Berat piknometer + air $\left(\mathrm{W}_{2}\right)$ & 1198 & 1200 \\
\hline Berat piknometer + Benda uji + air $\left(\mathrm{W}_{1}\right)$ & 1492 & 1485 \\
\hline \multirow{2}{*}{ Berat jenis kering $=\frac{B K}{\left(W_{2}+500-W_{1}\right)}$} & $2,354 \%$ & $2,298 \%$ \\
\cline { 2 - 4 } & Rata - rata $=2,326$ \\
\hline \multirow{2}{*}{ Berat jenis SSD $=\frac{B j}{\left(W_{2}+500-W_{1}\right)}$} & $2,427 \%$ & $2,326 \%$ \\
\cline { 2 - 4 } & \multicolumn{2}{|c|}{ Rata - rata $=2,377$} \\
\hline \multirow{2}{*}{ Penyerapan = $\frac{3 j-B k)}{B k} x 100 \%$} & \multicolumn{2}{|c|}{ Rata - rata $=2,154 \%$} \\
\cline { 2 - 4 }
\end{tabular}

Sumber : Hasil penelitian 
Tabel 4.9. Pemeriksaan Berat Isi Gembur Agregat kasar

\begin{tabular}{|l|c|c|}
\hline \multicolumn{1}{|c|}{ Pemeriksaan } & $\begin{array}{c}\text { I } \\
\text { (gram) }\end{array}$ & $\begin{array}{c}\text { II } \\
\text { (gram) }\end{array}$ \\
\hline Berat cawan $\left(\mathrm{W}_{1}\right)$ & 854 & 2211 \\
\hline Berat cawan + Benda uji $\left(\mathrm{W}_{2}\right)$ & 3212 & 5567 \\
\hline Berat benda uji $\left(\mathrm{W}_{3}=\mathrm{W}_{2}-\mathrm{W}_{1}\right)$ & 2358 & 3356 \\
\hline Volume cetakan $(\mathrm{V})$ & 1710,60 & 2493,46 \\
\hline Berat isi gembur $=\frac{W_{3}}{V}$ & 1,38 & 1,35 \\
\hline Berat isi gembur rata-rata & \multicolumn{2}{|c|}{$1,37 \mathrm{gr} / \mathrm{cm}^{3}$} \\
\hline
\end{tabular}

Sumber : Hasil penelitian

Tabel 4.10. Pemeriksaan Berat Isi Padat Agregat kasar

\begin{tabular}{|l|c|c|}
\hline \multicolumn{1}{|c|}{ Pemeriksaan } & I (gram) & II (gram) \\
\hline Berat cawan $\left(\mathrm{W}_{1}\right)$ & 854 & 2211 \\
\hline Berat cawan + Benda uji $\left(\mathrm{W}_{2}\right)$ & 3516 & 6038 \\
\hline Berat benda uji $\left(\mathrm{W}_{3}=\mathrm{W}_{2}-\mathrm{W}_{1}\right)$ & 2662 & 3827 \\
\hline Volume cetakan $(\mathrm{V})$ & 1710,60 & 2493,46 \\
\hline Berat isi padat $=\frac{W_{3}}{V}$ & 1,56 & 1,54 \\
\hline Berat isi padat rata-rata & \multicolumn{3}{|c|}{$1,55 \mathrm{gr} / \mathrm{cm}^{3}$} \\
\hline
\end{tabular}

Sumber : Hasil penelitian

Dari hasil pemeriksaan berat isi agregat kasar, didapatkan berat isi agregat kasar rata - rata untuk keadaan gembur $=1,37$ gr $/ \mathrm{cm}^{3}$, sedangkan untuk berat isi agregat kasar rata - rata untuk keadaan padat $=1,55 \mathrm{gr}$ $/ \mathrm{cm}^{3}$

Tabel 4.11. Pemeriksaan Analisa Saringan Agregat kasar

\begin{tabular}{|c|c|c|c|c|}
\hline \multirow{2}{*}{$\begin{array}{l}\text { Ukuran } \\
\text { Saringa } \\
\mathrm{n}(\mathrm{mm})\end{array}$} & \multicolumn{2}{|c|}{$\begin{array}{l}\text { Agregat } \\
\text { Tertahan }\end{array}$} & \multicolumn{2}{|c|}{$\begin{array}{l}\% \text { Kumulatif } \\
\text { Agregat }\end{array}$} \\
\hline & gram & $\%$ & Tertahan & Lolos \\
\hline 37,5 & 0 & 0 & 0 & 100 \\
\hline 19 & 11 & 0,37 & 0,37 & 99,63 \\
\hline 9,5 & 2477 & 82,56 & 82,93 & 17,07 \\
\hline 4 & 470 & 15,66 & 98,59 & 1,41 \\
\hline 2 & 2 & 0,07 & 98,66 & 1,34 \\
\hline 1 & 15 & 0,5 & 99,16 & 0,84 \\
\hline 0,5 & 5 & 0,17 & 99,33 & 0,67 \\
\hline 0,25 & 3 & 0,1 & 99.42 & 0,58 \\
\hline 0,125 & 2 & 0,07 & 99,5 & 0,5 \\
\hline 0,063 & 12 & 0,4 & 99,4 & 0,6 \\
\hline PAN & 3 & 0,1 & 100 & 0 \\
\hline Jumlah & 3000 & 100 & 877,36 & \\
\hline \multicolumn{5}{|c|}{ Angka Kehalusan $=\frac{\frac{\text { Total \% kumulatif tertahan }}{100}}{\frac{877,36}{100}}=8,77$} \\
\hline
\end{tabular}

Sumber : Hasil penelitian

\section{Hasil pengujian slump beton}

\begin{tabular}{|c|c|}
\hline Beton & Nilai slump $(\mathrm{cm})$ \\
\hline Normal & 9,7 \\
\hline Pengganti Agregat Kasar 5\% & 8,3 \\
\hline Pengganti Agregat Kasar 10 \% & 7 \\
\hline Pengganti Agregat Kasar 15 \% & 6,3 \\
\hline
\end{tabular}

Sumber : Hasil penelitian

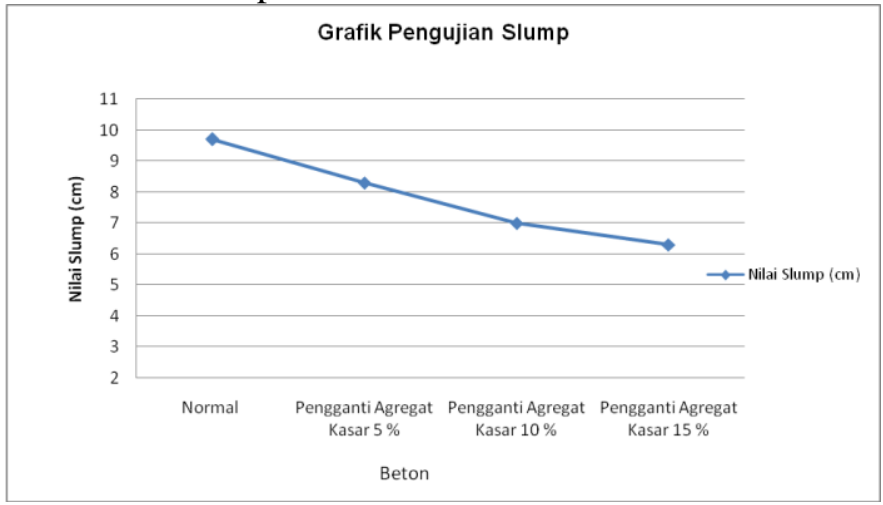

Grafik 4.1. Pengujian Slump

Berdasarkan grafik tersebut dapat diketahui bahwa slump yang dicapai mulai dari beton normal, beton dengan material limbah pecahan Tempurung Kelapa sebagai bahan pengganti agregat kasar 5\%, 10\%, 15\% masih memenuhi slump yang disyaratkan antara 60 $100 \mathrm{~mm}$.

\section{Hasil Pengujian Kuat tarik Belah Silinder Beton}

Pengujian kuat tarik belah silinder beton dilakukan pada umur 7, 14, 21 dan 28 hari dengan memberikan tegangan tarik pada beton. Kekuatan tarik belah beton relatif rendah, kira-kira 10\%-15\% dari kekuatan tekan beton. Pada dasarnya pengujian kuat tarik belah beton mengacu pada SNI 03-2491-2014 "Metode uji kekuatan tarik belah spesimen beton silinder".

Tabel 4.13. Rekapitulasi kuat tarik belah beton

\begin{tabular}{|l|c|c|c|c|}
\hline \multirow{2}{*}{$\begin{array}{c}\text { Kuat tarik } \\
\text { pelah beton } \\
\text { rata-rata }\end{array}$} & $\begin{array}{l}\text { Nor } \\
\text { mal }\end{array}$ & $\begin{array}{l}\text { Pengganti } \\
\text { Agregat } \\
\text { Kasar 5\% }\end{array}$ & $\begin{array}{l}\text { Pengganti } \\
\text { Agregat } \\
\text { Kasar 10 \% }\end{array}$ & $\begin{array}{l}\text { Pengganti } \\
\text { Agregat } \\
\text { Kasar 15 \% }\end{array}$ \\
\hline $\begin{array}{l}\text { Umur 7 } \\
\text { hari }\end{array}$ & 3,19 & 2,52 & 2,52 & 2,30 \\
\hline $\begin{array}{l}\text { Umur } \\
14 \text { hari }\end{array}$ & 3,85 & 3,11 & 2,89 & 2,50 \\
\hline $\begin{array}{l}\text { Umur } \\
21 \text { hari }\end{array}$ & 4,22 & 3,33 & 2,96 & 2,89 \\
\hline $\begin{array}{l}\text { Umur } \\
28 \text { hari }\end{array}$ & 4,89 & 3,70 & 3,41 & 3,33 \\
\hline
\end{tabular}

Sumber : Hasil penelitian 


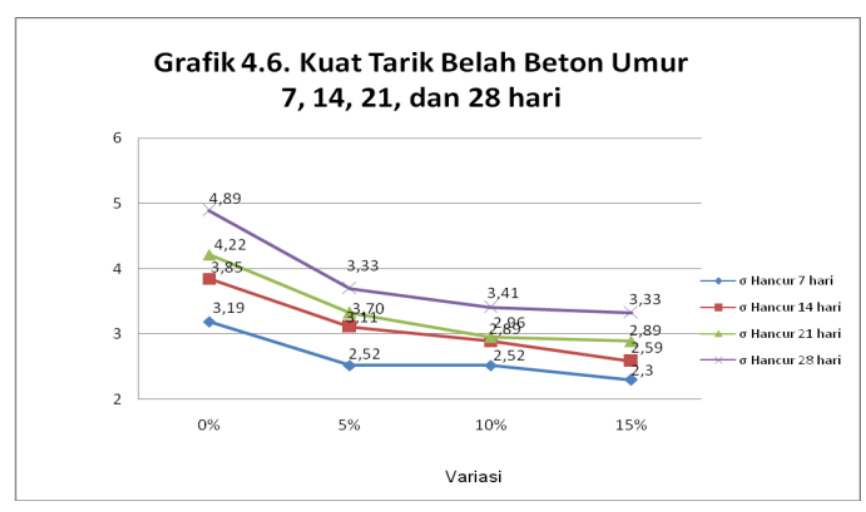

\section{PENUTUP}

\section{A. Kesimpulan}

Dari penelitian yang telah dilaksanakan dan dari hasil penelitian yang telah dicapai, penulis dapat menarik kesimpulan sebagai berikut :

$>$ Nilai slump yang di dapat dengan penambahan limbah pecahan tempurung kelapa sebagai bahan pengganti agregat kasar 5\%, 10\%, 15\% masih memenuhi slump yang disyaratkan antara $60-100$ $\mathrm{mm}$.

$>$ Hasil Analisis kuat tarik belah beton yang dicapai oleh beton tanpa menggunakan material pengganti agregat kasar atau beton normal pada umur 7 hari kuat tarik belah beton 3,19 N/mm2, pada umur 14 hari 3,85 $\mathrm{N} / \mathrm{mm}^{2}$, pada umur 21 hari $4,22 \mathrm{~N} / \mathrm{mm}^{2}$, dan 28 hari $4,89 \mathrm{~N} / \mathrm{mm}^{2}$, terlihat semakin meningkat sampai 28 hari diatas kuat tarik belah beton rencana $3,76 \mathrm{~N} / \mathrm{mm}^{2}$.

> Hasil Analisis kuat tarik belah beton yang dicapai oleh beton dengan menggunakan limbah pecahan tempurung kelapa atau material pengganti agregat kasar 5\%, 10\%, $15 \%$ kuat tarik belah beton pada umur 7 , 14, 21, dan 28 hari kuat tarik belah beton relatif turun.

> Penambahan variasi limbah pecahan tempurung kelapa sebagai pengganti agregat kasar mengakibatkan penurunan kekuatan beton.

\section{B. Saran}

Setelah melakukan penelitian ini, penulis mempunyai saran yang mungkin dapat berguna bagi peneliti selanjutnya, yaitu :

> Perlu dilakukan penelitian lanjutan dengan variasi persentase pengganti agregat kasar yang berbeda dan pengujian umur beton lebih dari 28 hari.
Perhatikan masa perawatan benda uji, karena sangat berpengaruh pada waktu pengujian.

$>$ Perlu kiranya diteliti nilai kuat tekan beton dengan limbah pecahan tempurung kelapa sebagai pengganti sebagian agregat kasar.

\section{DAFTAR PUSTAKA}

[1] Anita Setyowati Srie Gunarti, Subari, Guntur Alam 2013, Pengaruh Penambahan Waterglass Pada Sifat Mekanik Beton. Jurnal BENTANG Volume 1, Nomor 1, Januari 2013.

[2] I Made Adi Wiranata, I N. Suprapta Winaya, dan A.A.I.A. Sri Komaladewi 2017, Studi Eksperimental Komposisi Campuran Arang Tempurung Kelapa (Char) dengan Bed Material Tanah Liat Pada Dual Reaktor Fluidized Bed. Jurnal Ilmiah TEKNIK DESAIN MEKANIKA Volume 6, Nomor 1, Januari 2017.

[3] Asrullah 2019, Analisa Kuat Tekan Beton Dengan Menggunakan Sika Concrete Refair Mortar dan Tempurung Kelapa Pada Campuran Beton K300. Jurnal Teknik Sipil Volume 9, Nomor 1, Mei 2019 ISSN.2089-2942

[4] Tjokrodimuljo, 1996, Teknologi Bahan Konstruksi, Buku Ajar. Jurusan Teknik Sipil, Universitas Atma Jaya. Yogyakarta.

[5] Tjokrodimuljo, 1992, Teknologi Bahan Konstruksi, Buku Ajar. Jurusan Teknik Sipil, Universitas Atma Jaya. Yogyakarta.

[6] Departemen Pekerjaan Umum, 1982. Persyaratan Umum Bahan Bangunan di Indonesia,. PUBI-1982, Departemen Pekerjaan Umum, Jakarta.

[7] SNI 03-6861.1-2002 Persyaratan Air untuk campuran beton, Badan Standarisasi Nasional

[8] Dewi Pugersari, Achmad Syarief, Dwinita Laeasari 2013, Eksperimen Pengembangan Produk Fungsional Bernilai Komersial Berbahan Tempurung Kelapa Berusia Muda dengan Teknik Pelunakan, ITB J. Vis. Art\&Des. Volume 5 Nomor I, 2013. Pp 74-91.

[9] SNI 03-1971-1990 Metode Pengujian Kadar Air Agregat, Badan Standarisasi Nasional.

[10] SNI 2491:2014 tentang metode uji kekuatan tarik belah spesimen beton silinder, Badan Standarisasi Nasional. 